DOI:10.36023/ujrs.2020.27.183

UDC (550.814.012:528.88):681.518:(504.064.3:628.542)](477)

\title{
Integration of GIS and RSE aiming to the effective monitoring of the surroundings of landfills
}

\author{
O. T. Azimov ${ }^{1 *}$, O. V. Shevchuk ${ }^{2}$, K. O. Azimova ${ }^{3}$, Ye. M. Dorofey ${ }^{1}$, O. V. Tomchenko ${ }^{1}$ \\ ${ }^{1}$ State Institution Scientific Centre for Aerospace Research of the Earth of the Institute of Geological Sciences of the \\ National Academy of Sciences of Ukraine, 55-B, O. Gonchar st., Kyiv 01054, Ukraine \\ ${ }^{2}$ Institute of Telecommunications and Global Information Space of NAS of Ukraine, 25 Chokolovskij bulv. ap.13, \\ Kyiv186, Ukraine \\ ${ }^{3}$ Independent expert, Kyiv, Ukraine
}

The article highlights the possibilities of using the technologies of remote sensing of the Earth (RSE) and geographic information systems (GIS) for monitoring studies of pollution factors of the environment within the municipal solid waste (MSW) dumps and landfill areas as well when the assessing their impact on the landscape components. The main purpose of the investigation is to formulate the general principles of creation and to determine the main components of the information system of geomonitoring of areas of impact of the MSW disposal landfills as part of an information-analytical system of analysis of the risk of emergencies of man-made and natural character, aimed at ensuring sustainable regional development of Ukraine. During the research of the Kyiv's Oblast territory, space imagery from IRS satellites was used. For detailed exploration of the individual sites where the largest landfill sites and areas are located (northern Obukhiv district, Bila Tserkva district, Trypillya district), were also used images from the Quick Bird satellite. The improvement of the characteristics of the Kyiv's landfill No 5 at the north of the Obukhiv district used the unmanned aerial vehicle data. Some of the factors that have a negative environmental impact on the environment and the population of MSW disposal landfills and the possibilities of monitoring them by RSE methods are considered in the article. As a result it has been shown that the RSE data integrated to GIS allow to obtain accurate information about the current state of the studied area quickly, to conduct timely monitoring and forecasting the development of negative phenomena and processes, which significantly increases the level of environmental safety at national, regional and site levels and provides an opportunity to develop a set of measures to reduce the environmental impact of MSW disposal landfills. The situation with waste, especially domestic waste in Kyiv's Oblast, is getting worse every year. As a result, there is an increasing threat to human and environmental health. The obtained results show that one of the reasons for the current situation is the selection of unfavorable sites for the allocation of waste disposal landfills.

Keywords: geoinformation systems, monitoring, environment, disposals, domestic waste.

(C) O. T. Azimov, O. V. Shevchuk, K. O. Azimova, Ye. M. Dorofey, O. V. Tomchenko. 2020

\section{The urgency of issue}

Nowadays, the problem of environmental pollution from landfills is very acute. According to the State Statistics Service of Ukraine (Waste..., 2019) 35-40 $\mathrm{mln} \mathrm{m}^{3}$ of solid waste is produced annually in our country. The total mass of accumulated waste in Ukraine is 25 bln tons, which, per one citizen, is about 600 tons. Specific solid waste generation for Ukraine averages $250 \mathrm{~kg} / \mathrm{per}$ year per person, and in large cities reaches 330-380 kg/year and tends to increase.

The total mass of the municipal solid waste (MSW) stream is annually about $400 \mathrm{mln}$ tons, $80 \%$ of which is destroyed by landfilling. For Ukraine this figure is over $13 \mathrm{mln}$ tons of MSW generations, of which $95 \%$ goes to landfills.

* E-mail: azimov@casre.kiev.ua

https://orcid.org/0000-0002-5210-3920

https://www.scopus.com/authid/

detail.uri?authorId $=5608453320$

Tel.: + 380669299491
To date, there are at least 12 sites in the Kyiv Region (landfills, sludge pits, ash disposal areas) that store industrial waste and 36 landfills (Fig. 1). Their total area is $472 \mathrm{ha}$; the amount of accumulated waste is $56.14 \mathrm{mln}$ tons. Unfortunately, $75 \%$ of unauthorized landfills and official landfills do not meet the sanitary requirements. Landfills and unauthorized landfills, acting as nature conservation facilities through landfill disposal and biodegradation, are themselves sources of negative environmental impact. Negative types of impact should include the removal of large areas of land for economic use for the long term, soil contamination and disturbance of their structure, pollution of air, groundwater and surface water, vegetation, increased fire risk and more.

The most serious problem is groundwater pollution. Seepage through the layers of landfilled waste leads to that the rainwater and melt water is "enriched" with various chemicals that are formed during the decomposition process, producing a dangerous leachate. Particularly problematic is the Kyiv Landfill No 5 near the village of Pidhirtsi, Obukhiv district (waste disposal services are provided by the Kyivspetstrans Joint-Stock Company), officially closed 


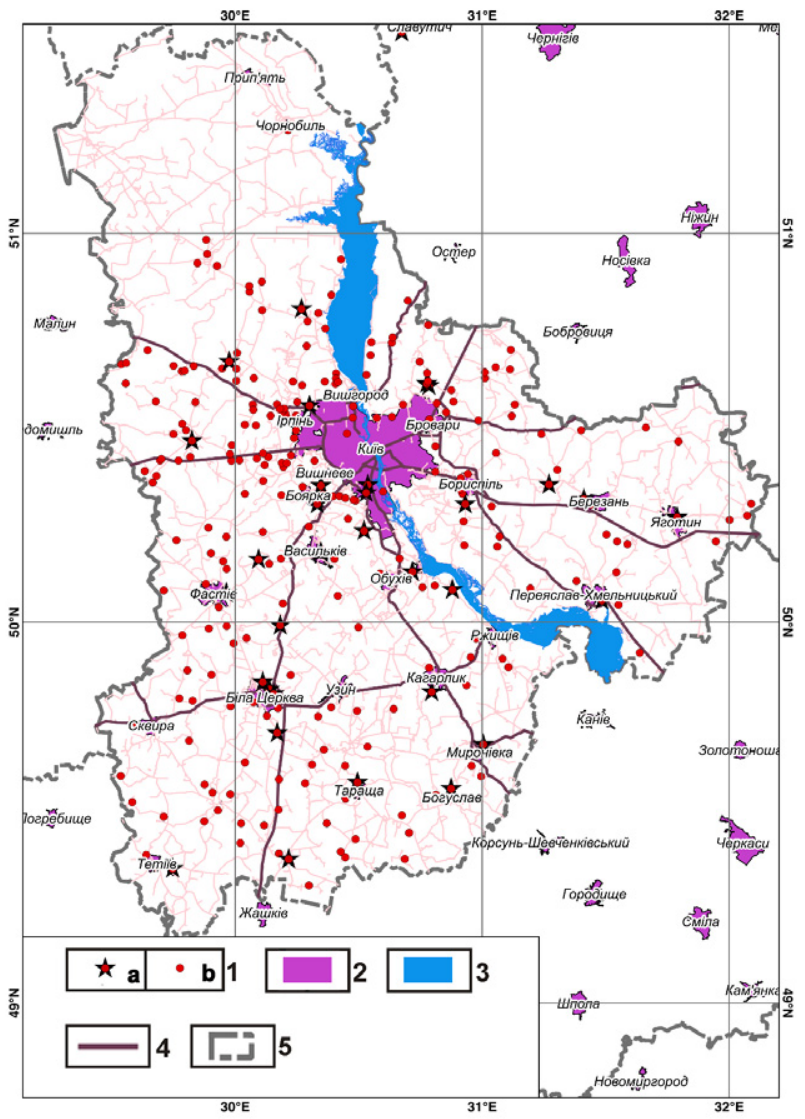

Fig. 1. Schematic map of the landfills localities within the Kyiv's Oblast area distinguishing by remote sensing data as of 2016. Compiled using materials (Tishaeva and Tomchenko, 2016). 1 landfills: a - authorized ones, $\mathrm{b}$ - of uncertain origins; 2 - cities and towns; 3 - water bodies; 4 - road traffic routes; 5 - Oblasts boundaries

Landfill No 6 in the area of the village of Pyrohovo near Kyiv City and the Landfill in Bila Tserkva City (subordinate to MATE1028 Joint-Stock Company). Characteristic of all districts of the region is the presence of a large number of unauthorized landfills, which pose a serious environmental risk, since there is a possibility of removal of pollutants directly into the water bodies.

\section{Purpose, methods, objectives and materials of research}

The main purpose of the article is to formulate the general principles of creation and to determine the main components of the information system of geomonitoring of areas of impact of the MSW disposal landfills as part of an information-analytical system of analysis of the risk of emergencies of man-made and natural character, aimed at ensuring sustainable regional development of Ukraine (Azimov et al., 2006).

The research, based on the method of analytical comparison, consisted in the elaboration and in a certain way of generalization of materials published in the scientific literature regarding information technologies for MSW landfills monitoring and management, predicting technogenic-ecological transformation of territories under their influence. Special emphasis was placed on analyzing the role of geoinformation systems in the developed or proposed technologies (Munn, 1973; Kukharskyi et al., 2013; Lyashchenko and Patrakeev, 2015).

Some practical aspects of implementation, approbation of information system of geomonitoring of areas of impact of MSW disposal landfills, developed or improved by us using technologies of remote sensing of the Earth - RSE (Azimov et al., 2018 a,b,c, 2019 a,b,c,d,e, 2020; Kuraeva et al., 2019; Trofymchuk et al., 2019 a; Shevchuk and Azimov, 2019; Azimov and Shevchuk, 2020), demonstrated by the example of the Kyiv region and several typical objects within it. In this context, we have now pursued the following main tasks:

- Study of the dynamics of landfill area change;

- Study of the status of individual sites (Sections) of landfills.

During the research, space imagery from IRS-1C and IRS-1D satellites (spatial resolution of $5.8 \mathrm{~m} /$ pixel for panchromatic image and $16 \mathrm{~m} /$ pixel for individual spectral bands, acquisition year of 2006) was used. For detailed exploration of the individual sites where the largest landfill sites and areas are located (northern Obukhiv district, Bila Tserkva district, Trypillya district), were also used images from the Quick Bird satellite (spatial resolution $0.6 \mathrm{~m} /$ pixel, acquisition year - 2006). The improvement of the characteristics of the Kyiv's landfill No 5 at the north of the Obukhiv district used the unmanned aerial vehicle (UAV) data.

\section{Outline of the main research material}

Review and synthesis of scientific literature sources on the basic structure of the information system for monitoring the major environmental components of MSW disposal landfill impact areas (Ahmed et al., 2006; Iacoboaea and Petrescu, 2013; Demesouka et al., 2014; Khan and Samadder, 2014; Deblina and Goel, 2017; Jimoh et al., 2019; Singh, 2019; Trofymchuk et al., 2019 b) allowed to determine the following stages and components of its creation:

1. Analysis of theoretical and scientific-methodological approaches and methods of geomonitoring of territories affected by MSW disposal landfills. The choice of approaches and methods based on geoinformation technologies, which are most suitable for practical implementation with the use of appropriate software.

2. Development of a model for estimation, analysis and forecasting of technogenic-ecological transformation of territories under the influence of MSW disposal landfills.

3. Modeling of environmental contamination situations in the area of MSW landfills exposure and their environmental consequences (including emergencies due to the accidental release of various toxicants).

4. Adaptation of estimation algorithms in accordance with the available information support to the input data.

5. Scientific and technical substantiation, design and program implementation of the prototype geomonitoring block of information-analytical assessment, analysis and forecasting of ecological and economic losses from the MSW disposal landfills activities in Ukraine.

6. Scientific and technical substantiation and development of the decision support block and its integration into a single structure of the existing prototype of the software complex of the information-analytical system for the MSW disposal landfills management.

7. Testing of the prototype system and its experimental operation.

In our opinion, modern technologies of geographic information systems (GIS) and technologies of RSE should take a prominent place in each of the mentioned blocks of the information system. In further improvement of the information system of environmental monitoring in the sites of MSW siting (or disposal) landfills and surrounding areas, which are affected by them, using the RSE/GIS-technologies, we see our prospects.

E. V. Shcherbina (Shcherbina, 2012) distinguishes the following periods of the life cycle of MSW disposal landfills: passive 
(conducting engineering studies at the stage of investment justification, performing an assessment of the existing state of the environment); active (creation, operation of landfills - Fig. 2, reclamation of landfills Fig. 3); passive (landfill closure). Therefore, the features of the use of geoinformation technologies, especially GIS and RSE technologies, will be discussed in more detail in the first of the specified periods of the cycle of existence and activity of the MSW disposal landfills.

Both at the beginning of the first (laying) and during the active cycle of a MSW disposal landfill for geomonitoring of the respective territory it is necessary to select remote images. The purpose of their use is to obtain the following information in the following: location (locality, district, coordinates), mode of operation (active, closed), characteristics (volume, area, ground, underground), type of waste and other characteristics of the MSW disposal landfill. To do this, use multiband satellite images of the highest spatial resolution acquired by such satellites as QuickBird,
Ikonos, Eros A, GeoEye-1, WorldView-2, etc., that allow to obtain terrain images of functioning urban ecosystems with spatial resolution close to $1 \mathrm{~m} / \mathrm{pixel}$ in panchromatic or multispectral ranges of electromagnetic waves.

Atmospheric and geometric correction of the images is required, which will allow them to be further camerally decoded, classified, and recognized by various objects on them. This can be done by both automated and semi-automated and interactive methods with the active participation of a specialist. However, it is also necessary to carry out standard measurements of the parameters of the MSW disposal landfill by geodetic methods, which will be able to make their identification more adequately.

During the active period of landfill functioning, the following types of monitoring should be carried out: monitoring of the MSW disposal process itself, monitoring of the ground cover temperature regimes, monitoring of biogas and leachate formation within its boundaries. Unmanned aerial vehicles should be used

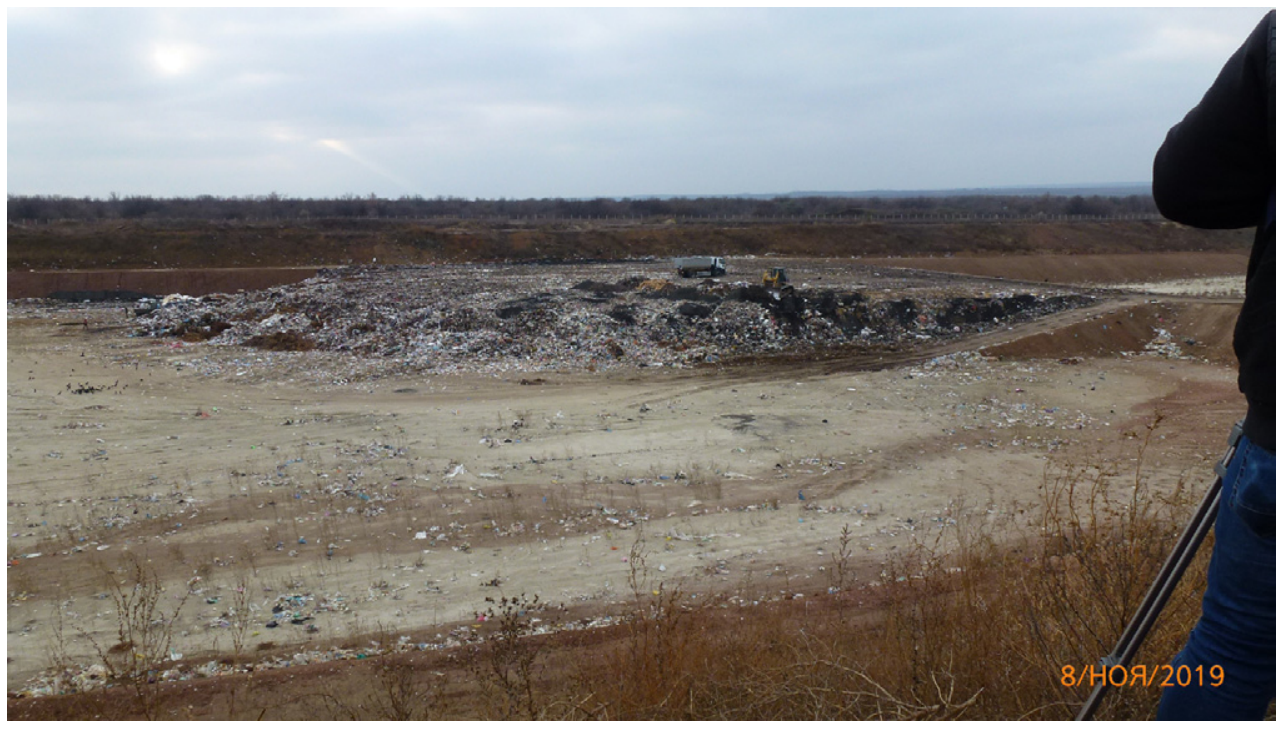

Fig. 2. New map of the municipal solid waste landfill for the city of Kramatorsk (the Donetsk's Oblast) at the initial operation. Picture taken by O. T. Azimov on 08.11.2019.

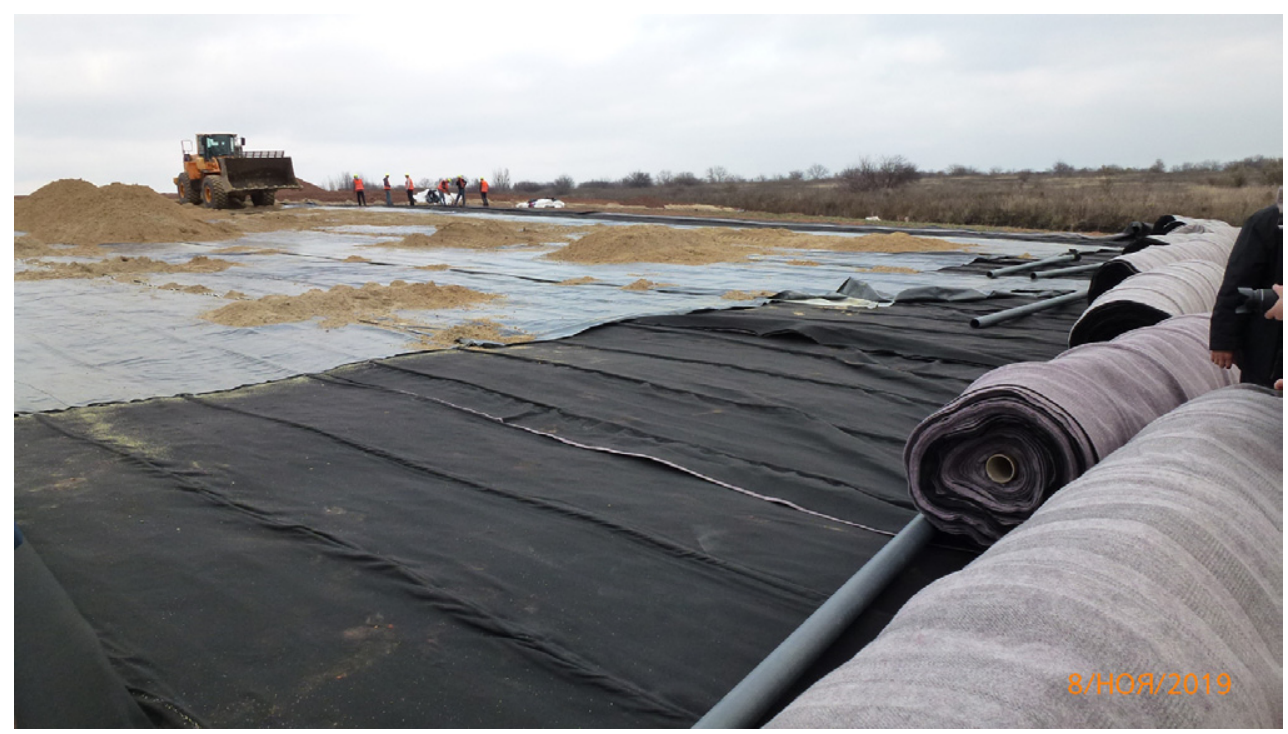

Fig. 3. The municipal solid waste landfill reclamation for the city of Sloviansk (the Donetsk's Oblast). Picture taken by O. T. Azimov on 08.11 .2019 
for modern landfill documentation, and should be presented as 3D models to improve the visualization of waste facilities. Thus, during the active period of the landfill functioning, the temporal surveys by the UAV will allow creating a database that will be useful for analyzing the operation of landfill, and the enterprise engaged in its operation and maintenance will be able to control the projected technological operations for waste disposal.

Such general control (of the entire MSW landfill disposal site) should occur twice a year in the inter-vegetation period (early spring and late autumn), when there is no vegetation at the landfill. Another function of control is to analyze the parameters of waste disposal on installed work sections (for example, the width of the working section up to $15 \mathrm{~m}$ and the length $-50-120 \mathrm{~m}$ ), control of the degree of compaction of the waste of the working section (until the sealed layer of waste reaches $2.0-2.5 \mathrm{~m}$ ), then cover it with an insulating layer (soil, clay, crushed construction waste) of at least $0.2 \mathrm{~m}$ thick. This must be done by modern GNSS receivers using the Global Navigation Satellite System in RTK (Real Time Kinematic) mode - real-time positioning, - or tachometric surveying. UAV data can be used by housing and communal services specialists, research institutions to perform engineering and design work.

Below are some of the factors that have a negative environmental impact on the environment and the population of MSW disposal landfills and the possibilities of monitoring them by RSE methods.

Monitoring the temperature of waste facilities. Landfill combustion has a high environmental risk because it leads to environmental pollution by toxic combustion products. A significant number of landfills have been burning for decades, despite their periodic extinguishing. There are theories that generally exclude the prevention of combustion and the burning of landfills. To ensure the proper quality of the environment and the health of population, it is necessary to eliminate the causes of fires in landfills and landfill sites and to control the prevention activities to prevent them.

One of such preventive measures are the use of space or aerial data in the infrared range of spectrum, based on the detection of thermal radiation of the surface and the objects placed on it, or data from specialized thermal imagers installed on the aircraft. The latter will help to fix the foci, areas of distribution of combustion, and subsequently — during their elimination. Therefore, these facilities can be used in the operation of MSW disposal landfills in general.

Monitoring of biogas and leachate production. The process of biogas formation results from the natural decomposition of organic matter. For its extraction it is necessary to install special wells located all over the body section of the landfill. Subsequently, gas is burned or processed for electricity.

Another component of the required monitoring is the leachate, which is mainly formed by the ingress of precipitation into the body of the landfill and seepage through it. The leachate enters the appropriate collectors. Thus, it is necessary to periodically measure the surface area of the leachate collectors and monitor their change on the basis of remote sensing images ( Fig. 4, 5, 6, 7). The problem of overflow of filter ponds is the increased pressure on the protective dams that can induce their deformations. In addition, the uplowing of leachate through the protective dams of the sumps due to their overfilling is one of the ways of contamination of the surface and underground hydrosphere by the leachate (Fig. 7, 8).

Another way of the going the leachate into the groundwater is the outbreak of the protective through the protective liners in the body of landfill. In general, this process can be illustrated by the logical path of the leachate impact on groundwater and the quality of drinking water for the population (Fig. 9).
In the post-exploitation period the spatial displacement of the body of MSW landfill is monitored. The reason for the landfill closure may be the expiration of their service life or emergencies (landslides, fires), protests by residents, non-compliance with operating standards and disposal of waste at landfill sites and others. After the landfill is closed, the process of stabilization of the body of the landfill takes place, which provides for the slopes to be positioned and brought back to normal at 18? (see Fig. 6, 7). When designing a reclamation project, it will be necessary to use topographic survey data, in particular: vertical planning, calculation of the required soil for insulation (top layer), to determine the distance from the MSW landfill to the nearest urban development sites, the area occupied directly by the waste. Subsequently, after technical and biological reclamation, it is necessary to carry out the laying of geodetic points, which will later serve to determine the spatial displacements of the body of the landfill.

As illustrative examples of the approbation of these approaches, in particular, we have established (Azimov et al., 2018c) that the detailed satellite images distinguish the state of the studied dumps, first of all their internal "structure": abandoned places covered by the soil layer; areas where waste is currently stored; the ponds for collection of leachate or separate areas where contaminated water is stagnant; access roads; ditches; etc. (see Fig. 4, 5, 10).

The satellite image shows the phenomenon of waste self-ignition in the MSW disposal landfill of Bila Tserkva City. This phenomenon is distinguished by a noticeable plume of smoke that spreads from the burning centre in the north-western part of the landfill (see Fig. 10).

The study of the dynamics of change in the area of the Bila Tserkva landfill range for a period of 20 years was performed using the spectrometric characteristics and texture of the images. Areas of the landfill that were used at different times were identified. Satellite images show the changes in vegetation in the surrounding areas, they provide the detecting of the paths to the landfill, which were used at different times (see Fig. 10).

Detailed studies of geodynamic safety and modern exogenous

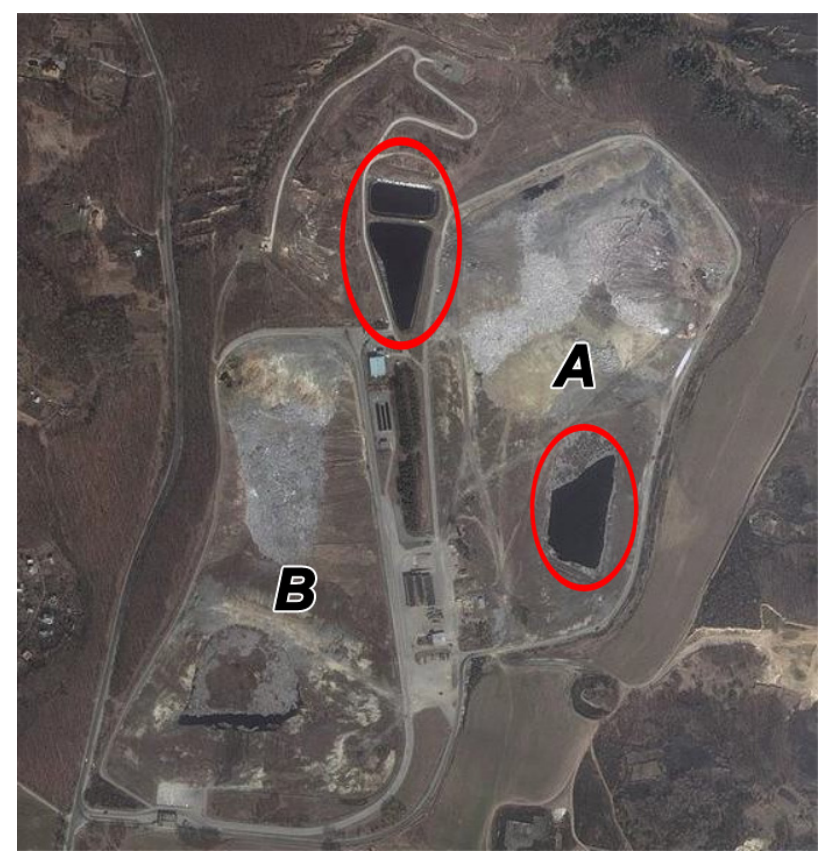

Fig. 4. Ouick Bird image of the Kyiv's Landfill No 5 as of 2006, where the areas of the water face of leachate ponds are identified clearly (outlined in red). $A, B-$ the Landfill Sections 


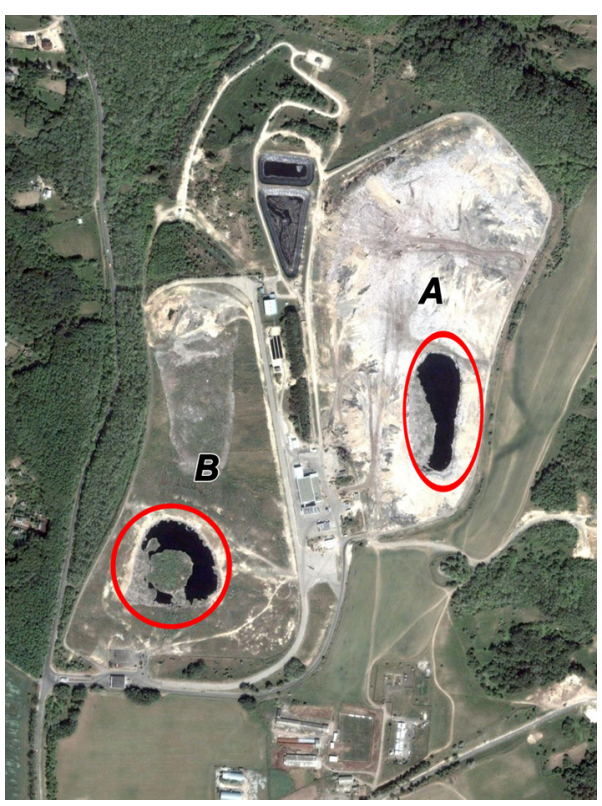

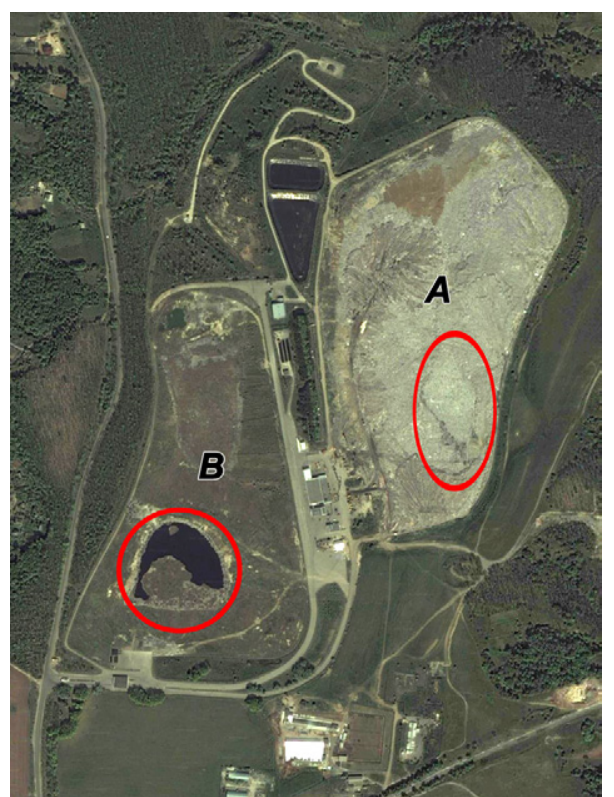

b

Fig. 5. Distinguishing the change of the leachate pond area (outlined in red) within the Landfill No 5 using the Quick Bird image of 26.05.2007 (a) and 10.05.2008 (b). A, B - the Landfill Sections

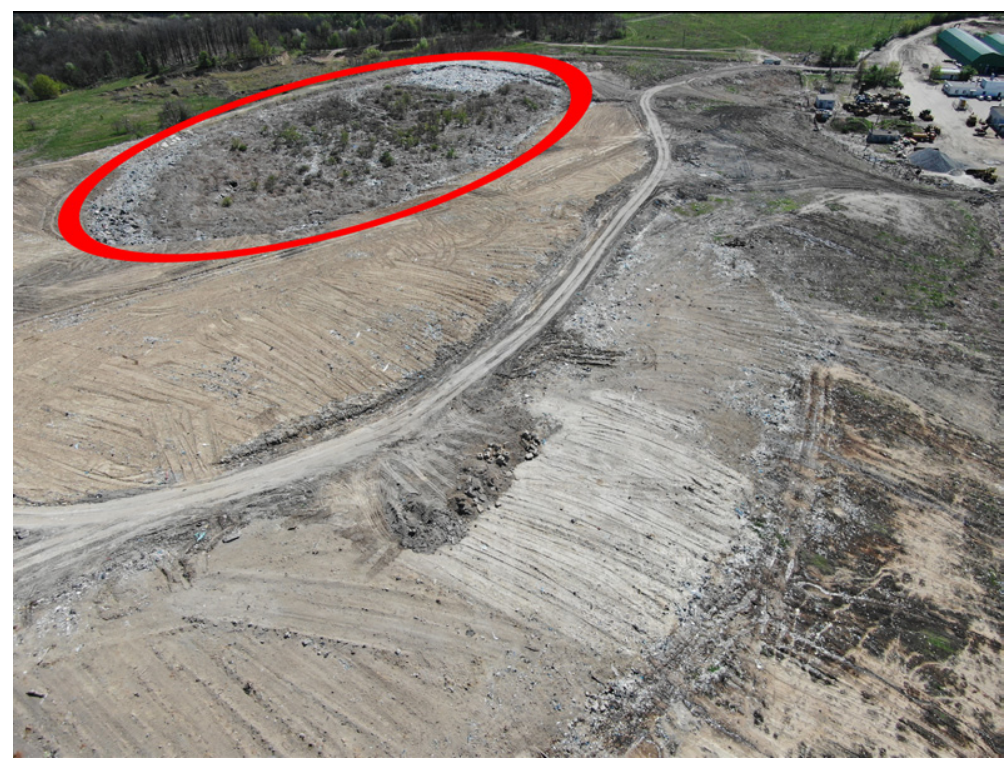

Fig. 6. Promising unmanned aerial vehicle image of the southern part of the Landfill No 5 Section «A» acquired on 31.05.2019, which allows controlling the landfill reclamation process (layering the inert soil) and distinguishing its inner «structure», passway through the landfill, leachate pond covered with the protected layer (outlined in red)

processes using Quick Bird images allow us to identify potentially hazardous areas on landfills, slurry pits and engineering infrastructure. These images also provide the distinguishing the landslides, active gullies, the areas of swamp development, deformations of the earth's surface at the places of old landfill sites, and other processes in need of attention.

In addition, the use of high spatial resolution images allow to identify the illegal dumping, sites of unauthorized discarding of waste (in particular, within the developments, in ravines, afforestation belts, etc.). Thus, several garbage dumps were made known within Kyiv City and its nearest outskirts: in a forest range near the Antonov State Enterprise, near the town of Vyshneve, in the area of low-rise buildings near the Sovsky ponds, in the area of summer residences near of Hlevaha settlement, etc.

\section{The main conclusion and prospects for the further studies}

The most effective tool for the analysis, management and planning of activities in the field of waste management is the introduction of an information system for geomonitoring the affected areas of landfills for the disposal and accumulation of waste based on the use of the RSE/ GIS-technologies. The RSE data integrated to GIS allow to obtain accurate information about the current state of the studied area quickly, to conduct timely monitoring and forecasting the development of negative phenomena and processes, which significantly increases the level of environmental safety at national, regional and site levels and provides an opportunity to develop a set of measures to reduce the environmental impact of MSW disposal landfills. 


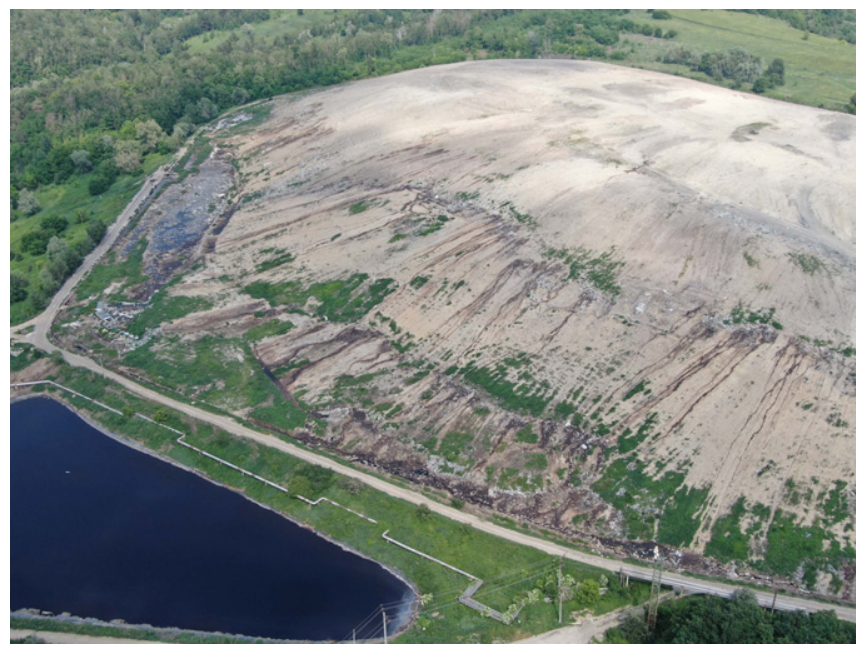

Fig. 7. Promising unmanned aerial vehicle image of the north-western part of Landfill No 5 acquired on 31.05.2019, where the percolation places of leachate (black brown color) from the landfill «body», its flowing down the slope and the accumulation at the Section «A» bottom, as well as the surface of the largest leachate collection pond are visible

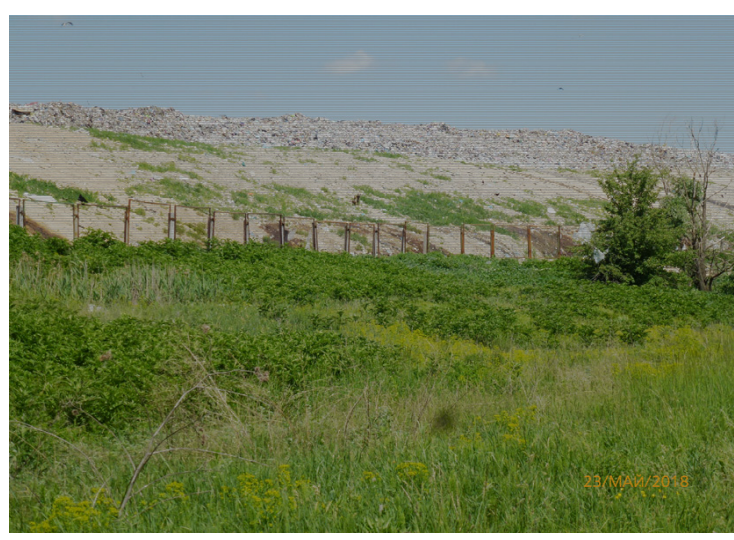

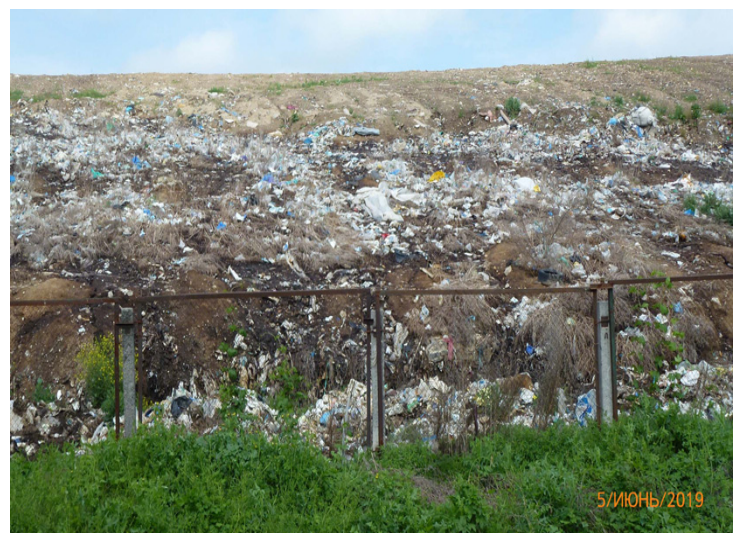

$\mathrm{b}$

Fig. 8. Photographic image of the eastern part of the Section «A» «body» of the Landfill No 5, where the percolation places of leachate and its flowing down the slope are marked out (black brown colour). Pictures taken by O. T. Azimov on 23.05.2018 (a) and 05.06.2019 (b)

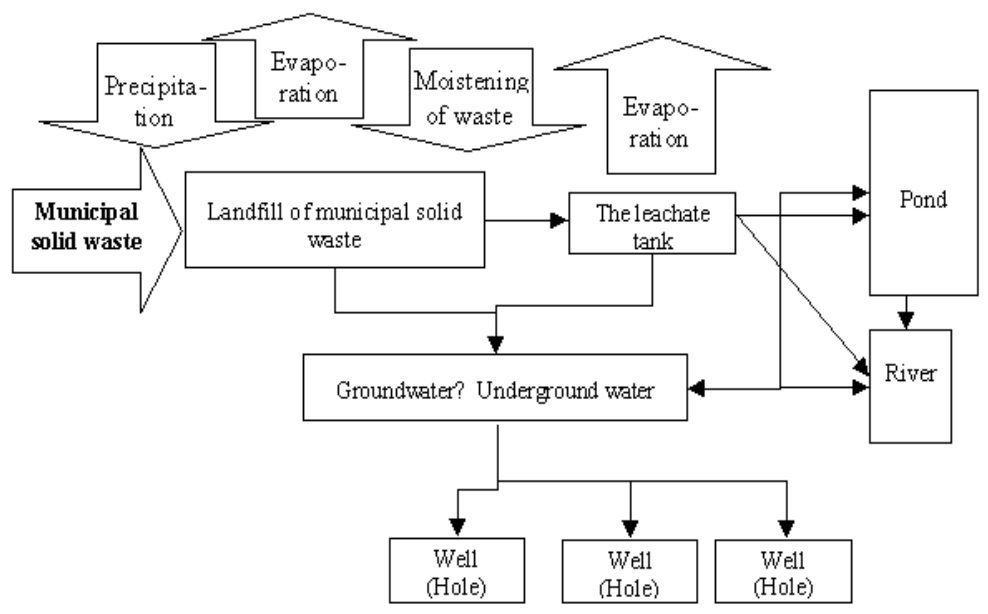

Fig. 9. Logical scheme of the effect of leachate on groundwater and drinking water quality for the population. Compiled using materials (Trofymchuk et al., 2019b), with additions. 


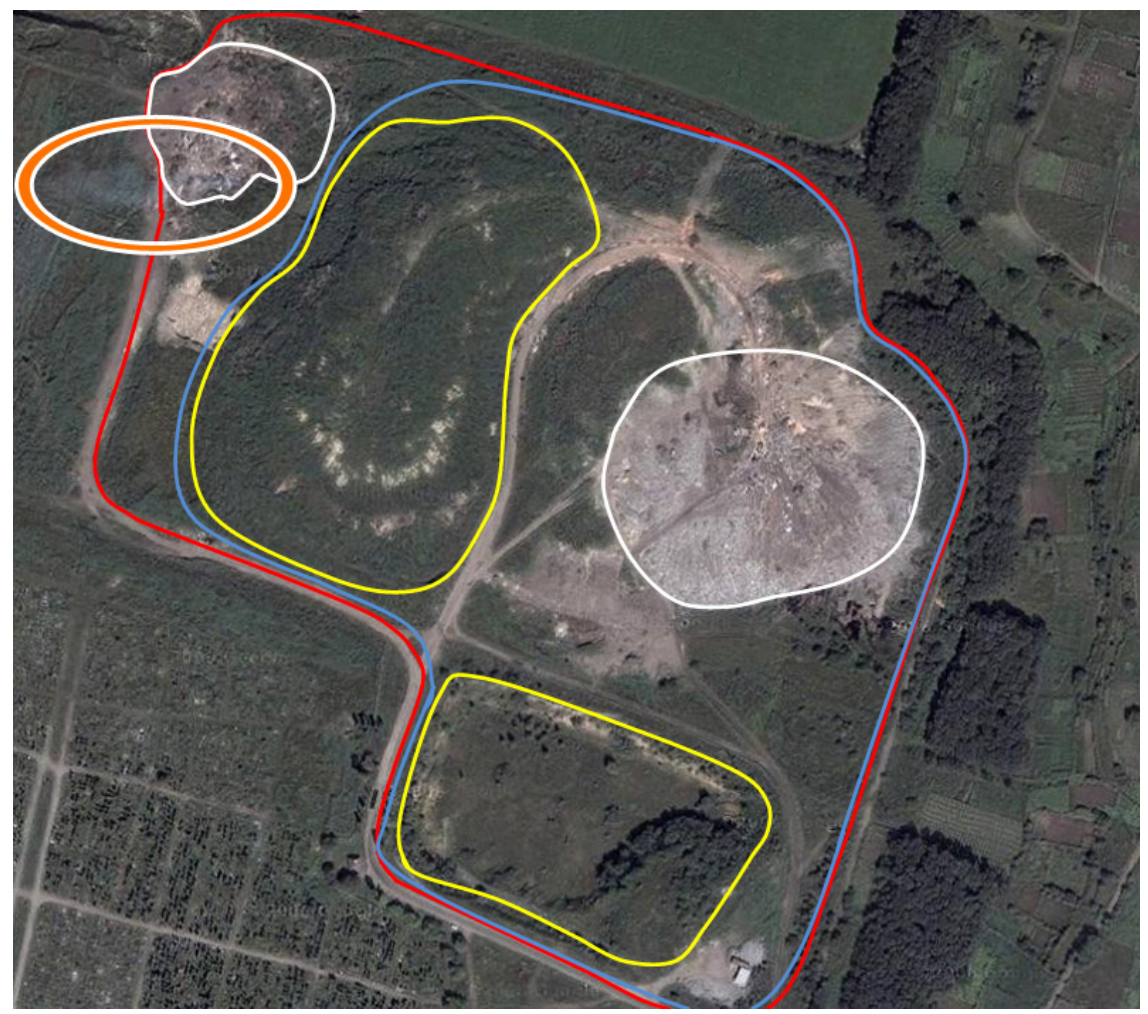

Fig. 10. Quick Bird image of the landfill site on the outskirts of Bila Tserkva as of 2006. Landfill outline is identified: its positions as of 1986 and 2006 are highlighted in blue and red, respectively. There are the Sections of municipal waste disposal as of 1986 (yellow) and as of 2006 (white). An orange oval outlines the place of waste self-ignition.

The situation with waste, especially domestic waste in Kyiv's Oblast, is getting worse every year. As a result, there is an increasing threat to human and environmental health. The obtained results show that one of the reasons for the current situation is the selection of unfavourable sites for the allocation of waste disposal landfills.

\section{Acknowledgement}

The authors are also grateful to the leadership of Pidhirtsi rural council, Obukhiv Raion, Kyiv Oblast in the person of S. S. Kravchenko for kindly provided data of the high spatial resolution UAV imaging over the Landfill area No 5.

\section{References}

Ahmed, Sh. M., Muhammad, H., \& Sivertun, A. (2006, September). Solid waste management planning using GIS and remote sensing technologies case study Aurangabad City, India. Pap. 2006 Int. Conf. Advances in Space Technologies (Islamabad, Pakistan), 196-200. doi: 10.1109/ICAST.2006.313826.

Azimov, O. T., Bakhmutov, V. G., Voytyuk, Yu. Yu., Dorofey, Ye. M., Karmazynenko, S. P., \& Kuraeva, I. V. (2018a, November) Reconnaissance integrated geoecological study of the disposal region for municipal solid waste with the aim of environmental assessment. Extended Abstr. 12th Int. Sci. Conf. on Monitoring of Geological Processes and Ecological Condition of the Environment, 5 p., Kyiv, Ukraine. doi: 10.3997/2214-4609.201803142.

Azimov, O. T., Dorofey, Ye. M., Trofymchuk, O. M., Kuraeva, I. V., Zlobina, K. S., \& Karmazynenko, S. P. (2019a, November). Monitoring and assessment of impact of municipal solid waste landfills on the surface water quality in the adjacent ponds. Proc. 13th Int. Sci. Conf. on Monitoring of Geological Processes and Ecological Condition of the Environment, 1-6, Kyiv, Ukraine. Retrieved from https://doi.org/10.3997/22144609.201903228.

Azimov, O. T., Korotynskyi, P. A., \& Koliesnichenko, Yu. Yu. (2006). The current state review of environmental and technogenous safety in Ukraine and perspects of developing the analytical interactive system for emergencies monitoring by means of remote sensing, telematical and GIS-technologies. Geoinformatyka - Geoinformatics (Ukraine), 4, 52-66. (in Ukrainian with English summary).

Azimov, O., Kuraeva, I., Bakhmutov, V., Voytyuk, Yu., \& Karmazynenko, S. (2019b). Assessment of the heavy metal distribution in soils within the areas for the municipal solid waste disposal. Visnyk Kyivskoho natsionalnoho universytetu imeni Tarasa Shevchenka. Heolohiia - Visnyk (Bull.) Taras Shevchenko Nat. Univ. of Kyiv: Geol. (Ukraine), 4 (87), 7680. Retrieved from http://doi.org/10.17721/1728-2713.87.11. (in Ukrainian with English abstract).

Azimov, O. T., Kuraeva, I. V., Karmazynenko, S. P., \& Zlobina, K. S. (2019c, June). Rational complex for the geochemical methods in the environment study of the municipal solid waste disposal areas. Proc. 6th Int. Geol. Forum «Actual problems and prospects of the development of geology: science and production», 1316, Odesa, Ukraine. Retrieved from http://ukrdgri.gov.ua/wpcontent/uploads/2019/06/material_geoforum_2019_1.pdf. (in Ukrainian with English summary).

Azimov, O. T., Kuraeva, I. V., Trofymchuk, O. M., Karmazynenko, S. P., Dorofey, Ye. M., \& Voytyuk, Yu.Yu. (2019d, May). Estimation of the heavy metal pollution for the soils and different environmental objects within the solid domestic waste landfills. Proc. 18th EAGE Int. Conf. on Geoinformatics Theoretical and Applied Aspects, 1-7, Kyiv, Ukraine. Retrieved from https://doi.org/10.3997/2214-4609.201902129. 
Azimov, O. T., Kuraeva, I. V., Voytyuk, Yu. Yu., Samchyk, A. I., Karmazynenko, S. P., \& Bakhmutov, V. G. (2018b). Ecologicalgeochemical assessment of the territories for the municipal solid waste disposal. Poshukova ta ekolohichna geokhimiia Explor. Environ. Geochem. (Ukraine), 1 (19), 22-26. (in Ukrainian with English summary).

Azimov, O. T., \& Shevchuk, O. V. (2020, May). Geoinformation systems in monitoring studies of environmental pollution factors in the areas of municipal solid waste landfills. Proc. 19th EAGE Int. Conf. on Geoinformatics - Theoretical and Applied Aspects, 1-7, (Kyiv, Ukraine). Retrieved from https://doi.org/10.3997/ 2214-4609.2020geo 111 .

Azimov, O. T., Tomchenko, O. V., Karmazynenko, S. P., Kuraeva, I. V., \& Voytyuk, Yu. Yu. (2018c, November). Monitoring the municipal solid waste landfill areas using the remote sensing technologies. Proc. Nat. Forum Waste management in Ukraine: legislation, economics, technologies. Program development on the waste management for the united territorial communities: key problematic issues and the best practices, 84-87, Kyiv. (in Ukrainian).

Azimov, O. T., Trofymchuk, O. M., Kuraeva, I. V., \& Karmazinenko, S. P. (2019 e). Estimations of heavy metals in soils and different landscape components within the municipal solid waste disposal areas. Ekolohichna bezpeka ta pryrodokorystuvannia - Environ. Safety Nat. Resources (Ukraine), 2 (30), 5-17. Retrieved from https://doi.org/10.32347/2411-4049.2019.2.5-17. Ukrainian with English abstract).

Azimov, O. T., Trofymchuk, O. M., Kuraeva, I. V., Zlobina, K. S., Karmazinenko, S. P., \& Dorofey, Ye. M. (2020, May). Ecological and geochemical study of the state of soil deposits in the impact areas of municipal solid waste landfills. Proc. 19th EAGE Int. Conf. on Geoinformatics - Theoretical and Applied Aspects, 1-7, Kyiv, Ukraine. Retrieved from https://doi.org/ 10.3997/2214-4609.2020geo133.

Deblina, D., \& Goel, S. (2017). Applications of remote sensing and GIS in solid waste management - A review. In S. Goel (Ed.), Advances in solid and hazardous waste management, 133-151. Cham: Springer. Retrieved from https://doi.org/10.1007/9783-319-57076-1_7

Demesouka, O. E., Vavatsikos, A. P., \& Anagnostopoulos, K. P. (2014). GIS-based multicriteria municipal solid waste landfill suitability analysis: A review of the methodologies performed and criteria implemented. Waste Manage. Res., vol. 32, iss. 4, 270-296. doi: 10.1177/0734242X14526632.

Iacoboaea, C., \& Petrescu, F. (2013). Landfill monitoring using remote sensing: a case study of Glina, Romania. Waste Manage. Res., vol. 31, iss. 10, 1075-1080. doi: 10.1177/ $0734242 X 13487585$.

Jimoh, R., Chuma, V., Moradeyo, A., Olubukola, O., Sedara, S. O., Yusuf, A., \& Jimoh, A. A. (2019). GIS based appraisal of waste disposal for environmental assessment and management in Mainland area of Lagos state, NG. Int. J. Environ. Geoinformatics (IJEGEO), vol. 6, iss. 1, 76-82. doi: 10.30897/ ijegeo.476449.

Khan, D., \& Samadder, S. R. (2014). Municipal solid waste management using Geographical Information System aided methods: A mini review. Waste Manage. Res., vol. 32, iss. 11, 1049-1062. doi: 10.1177/0734242X14554644.

Kukharskyi, I. A., Podlipaiev, V. O., Shumeiko, V. O., \& Atrasevych, O. V. (2013). Monitoring of ecologically dangerous objects using technologies and materials remote sensing. Nauka i tekhnika Povitrianykh Syl Zbroinykh Syl Ukrainy - Sci. Tech. Air Force of Ukraine (Ukraine), 4 (13), 113-116. Retrieved from http:// www.hups.mil.gov.ua/periodic-app/article/556. (in Ukrainian with English summary).
Kuraeva, I., Azimov, O., Voytyuk, Yu.Yu., Karmazynenko, S., Zlobina, K., \& Laktionova, O. (2019, May). Geochemical transformation environmental objects on the territories of solid domestic waste landfills (on the example of Kiev region landfill N 5). Abstr. Sci. Conf. Achievements and Development of the Geological Sciences in Ukraine, dedicated to the 50th Anniversary of M. P. Semenenko Inst. of Geochemistry, Mineralogy and Ore Formation. (vol. 2), 131-132, Kyiv. (in Ukrainian).

Lyashchenko, A., \& Patrakeev, I. (2015) Ontology and features of components geoinformation monitoring for geospatial database technology. Suchasni dosiahnennia heodezychnoi nauky ta vyrobnytstva - Modern Achievements Geodetic Sci. Prod. (Ukraine), 1 (29), 174-177. Retrieved from http://nbuv.gov.ua/ UJRN/sdgn_2015_1_42. (in Ukrainian with English summary).

Munn, R. E. (1973). Global environmental monitoring system (GEMS): Action plan for phase I (SCOPE Report 3). Toronto, Canada: Int. Council Sci. Unions, SCOPE. Retrieved from https:/ /www-legacy.dge.carnegiescience.edu/SCOPE/SCOPE_3/ scope_3.pdf.

Shcherbina, E. V. (2012). Methodology of life cycle analysis in the design of municipal solid waste landfills. Urbanistika, stroitelstvo, ekologia: Konsultatsii, retsenzii, proekti, otsenka spetsialistov - Urban Sci., Construction \& Ecology: Consultation, Reviews, Projects \& Expert Assess. (Russia). Retrieved from http://lerschtul.ru/ocologi/ metodologiya-analiza-zhiznennogo-cikla-pri-proektirovaniipoligonov-tverdyx-bytovyx-otxodov.html (in Russian).

Shevchuk, O. V., \& Azimov, O. T. (2019, November). Essence of geoinformational monitoring of the municipal solid waste landfills. Proc. 16th Sci. \& Tech. Conf. for the students, postgraduates, doctoral students, and young scientists Innovation technologies. K. O. Babikova, L. M. Melnychuk (Eds.), 288-293, Kyiv. Retrieved from http://cnt.nau.edu.ua/ sites/default/files/pictures/zbirnuk_20_11_19-1-min.pdf. (in Ukrainian).

Singh, A. (2019). Remote sensing and GIS applications for municipal waste management. J. Environ. Manage., 243, 22-29. doi: 10.1016/j.jenvman.2019.05.017.

Tishaeva, A. M., \& Tomchenko, O. V. (2016, October). Localization and identification of patterns for the spatial distribution of landfill sites at the terrain of the Kyiv's Oblast using RSE data. Proc. 15th Int. Sci. \& Practical Conf. Modern Information Technologies of the Ecological Management, Natural Resource Use and Emergency Measures, 54-56, Kyiv. Retrieved from https://itgip.org/wp-content/uploads/2013/11/Zbirka.pdf. (in Ukrainian).

Trofymchuk, O. M., Azimov, O. T., Kuraeva, I. V., Zlobina, K. S., \& Karmazynenko, S. P. (2019a, October). Features of the monitoring hydrosphere processes within the techno-ecosystems of the solid municipal waste disposal areas using remote sensing technologies. In S. O. Dovhyi (Ed.), Multi-authored monograph based on the 18th Int. Sci. \& Practical Conf. Proc. - Modern Information Technologies of the Ecological Management, Natural Resource Use and Emergency Measures: Topical Issues, 72-76, Kyiv. Retrieved from https://itgip.org/wp-content/ uploads/2019/10/1_Книга_сайт.pdf). (in Ukrainian).

Trofymchuk, O. M., Rogozhin, O. G., Khlobystov, Ye. V., Trofymchuk, V. O., Novokhatska, N. A., Vasyniuk, A. V., Kodatskyi, M. B., \& Kreta, D. L. (2019b). Information technologies for landfill management in ensuring sustainable regional development: Final report on research. No SR 0115U004148. Kyiv: Inst. Telecommunications \& Global Information Space, NAS of Ukraine. (in Ukrainian).

Waste. Statistical information. Economic statistics / Environment. (2019). Kyiv: State Statistics Service of Ukraine. Retrieved from http://www.ukrstat.gov.ua/. (in Ukrainian). 
ІНТЕГРУВАННЯ ГІС ТА ДЗЗ З МЕТОЮ ЕФЕКТИВНОГО МОНІТОРИНГУ ДОВКІЛЛЯ ТЕРИТОРІЙ СМІТТЄЗВАЛИЩ О. Т. Азімов, О. В. Шевчук, К. О. Азімова, Є. М. Дорофей, О. В. Томченко

ДУ “Науковий центр аерокосмічних досліджень Землі ІГН НАН Украӥни”, вул. О. Гончара 55 Б, Київ $01054, \quad$ Украӥна

У статті висвітлюються можливості застосування технологій дистанційного зондування Землі (ДЗ3) і географічних інформаційних систем (ГІС) у процесі моніторингових досліджень факторів забруднення довкілля у районах сміттєзвалищ і полігонів захоронення твердих побутових відходів (ТПВ), а також під час оцінки їхнього впливу на компоненти ландшафту. Головна мета досліджень полягає у формуванні загальних принципів створення і у визначенні основних складових інформаційної системи геомоніторингу районів впливу полігонів захоронення ТПВ, як частини інформаційно-аналітичної системи аналізу ризику виникнення надзвичайних ситуацій техногенного та природного характеру, спрямованої для забезпечення сталого регіонального розвитку України. У процесі досліджень території Київській області застосовувалися космічні знімки з супутників IRS. Для детальних досліджень на окремих ділянках, де розташовані найбільші за площею і своїми обсягами сміттєзвалища (північна частина Обухівського району, район м. Біла Церква, район м. Трипілля), також були використані знімки з космічного апарата Quick Bird. А для деталізації особливостей Київського полігона № 5 на півночі Обухівського району були використані дані, отримані з безпілотного літального апарата. У статті розглядаються деякі чинники негативного екологічного впливу на природне середовище і населення полігонів захоронення ТПВ і можливості їх моніторингу засобами Д33. У результаті проведеної роботи зроблено висновок, що найефективнішим засобом для аналізу, управління та планування діяльності у сфері поводження з різноманітними відходами є впровадження інформаційної системи геомоніторингу районів впливу полігонів їх захоронення або накопичення, що основана на застосуванні Дз3/ГІС-технологій. Інтегровані у ГІС дані ДЗ3 дозволяють оперативно отримувати достовірну інформацію про поточний стан територій, що досліджуються, проводити своєчасний контроль і прогнозування розвитку негативних явищ і процесів, які на них відбуваються. Це значно підвищує ступінь екологічної безпеки на державному, регіональному та об'єктовому рівнях і надає можливість розробити комплекс заходів щодо зменшення впливу на довкілля полігонів захоронення відходів різного походження. Ситуація 3 відходами, особливо 3 побутовими, у Київській області щороку погіршується. Унаслідок цього зростає загроза для здоров'я населення і для екологічного стану довкілля відповідних територій. Отримані результати показують, що однією з причин ситуації, що склалася, є вибір несприятливих ділянок, у межах яких розміщені полігони захоронення відходів.

Ключові слова: геоінформаційні системи, моніторинг, довкілля, сміттєзвалища, побутові відходи

\section{ИНТЕГРИРОВАНИЕ ГИС И ДЗЗ С ЦЕЛЬЮ ЭФФЕКТИВНОГО МОНИТОРИНГА ОКРУЖАЮЩЕЙ СРЕДЫ ТЕРРИТОРИЙ} МУСОРНЫХ СВАЛОК

А. Т. Азимов, А. В. Шевчук, Е. А. Азимова, Е. Н. Дорофей, О. В. Томченко

ГУ “Научный центр аэрокосмических исследований Земли ИГН НАН Украины”, ул. Олеся Гончара 55-Б, Киев, Украина, 01054

В статье освещаются возможности применение технологий дистанционного зондирования Земли (ДЗ3) и географических информационных систем (ГИС) в процессе мониторинговых исследований факторов загрязнения окружающей среды в районах мусорных свалок и полигонов захоронения твердых бытовых отходов (ТБО), а также при оценке их влияния на компоненты ландшафта. Главная цель исследований заключается в формировании общих принципов создания и в определении основных составляющих информационной системы геомониторинга районов влияния полигонов захоронения ТБО, как части информационноаналитической системы анализа риска возникновения чрезвычайных ситуаций техногенного и природного характера, направленной для обеспечения стабильного регионального развития Украины. В процессе исследований территории Киевской области применялись космические снимки со спутников IRS. Для детальных исследований на отдельных участках, где размещены самые большие по площади и своим объемам мусорные свалки (северная часть Обуховского района, район г. Белая Церковь, район г. Триполье), также были использованы снимки с космического аппарата Quick Bird. А для детализации особенностей Киевского полигона № 5 на севере Обуховского района были использованы данные, полученные с беспилотного летательного аппарата. В статье рассматриваются некоторые факторы негативного экологического влияния на окружающую среду и население полигонов захоронения ТБО и возможности их мониторинга средствами ДЗ3. В результате проведенной работы сделан вывод, что самым эффективным способом для анализа, управления и планирования деятельности в сфере обращения с различными отходами является внедрение информационной системы геомониторинга районов влияния полигонов их захоронения либо накопления, которая основана на применении ДзЗ/ГИСтехнологий. Интегрированные в ГИС данные ДЗ3 позволяют оперативно получать достоверную информацию о текущем состоянии исследуемых территорий, проводить своевременный контроль и прогнозирование развитие негативных явлений и процессов, которые на них происходят. Это значительно повышает степень экологической безопасности на государственном, региональном и объектовом уровнях и дает возможность разработать комплекс мер по уменьшению влияния на окружающую среду полигонов захоронения отходов различного происхождения. Ситуация с отходами, особенно с бытовыми, в Киевской области ежегодно ухудшается. Вследствие этого возрастает угроза для здоровья населения и для экологического состояния окружающей природной среды соответствующих территорий. Полученные результаты показывают, что одной из причин сложившейся ситуации является выбор неблагоприятных участков, в пределах которых размещены полигоны захоронения отходов.

Ключевые слова: геоинформационные системы, мониторинг, окружающая среда, мусорные свалки, бытовые отходы 